\title{
Impacts of human activities and climate change on the water environment of Lake Poyang Basin, China
}

Xinyan Li*, Lu Zhang, Guishan Yang, Hengpeng Li, Bin He, Yuwei Chen and Xuguang Tang

\begin{abstract}
Background: The global mean temperature has risen by $0.85^{\circ} \mathrm{C}$ from 1880 to 2012 , and this increase may even accelerate in the future. The surface temperatures of large inland water bodies worldwide have been rapidly warming since 1985 with an average rate of $0.045 \pm 0.011^{\circ} \mathrm{C} \mathrm{yr}^{-1}$ and rates as high as $0.10 \pm 0.01{ }^{\circ} \mathrm{C} \mathrm{yr}^{-1}$. The global climate change was responsible for an increased contribution of diffuse nutrient losses to the total nutrient loads in water bodies. More and more algae blooms were reported in inland water bodies. Lake Poyang, the largest freshwater lake in China, is experiencing a deterioration of water quality. Ganjiang River, as the longest river in the Lake Poyang catchment, plays an important role in linking between terrestrial and aquatic ecosystems. A large amount of N pollutants is transported through the Ganjiang River to Lake Poyang. It is important to study quantitatively human enhanced N (nitrogen) inputs and DIN (Dissolved Inorganic Nitrogen) exports through rivers in the background of global warming.

Results: In this paper, we estimate the inputs of nitrogen $(\mathrm{N})$ and exports of dissolved inorganic nitrogen (DIN) from the Ganjiang River to Lake Poyang for the period 1995-2010 by using the Global NEWS-DIN model. Modeled DIN yields range from $1038 \mathrm{~kg} \mathrm{~N} \mathrm{~km}^{-2} \mathrm{yr}^{-1}$ in 1995 to $150 \mathrm{~kg} \mathrm{~N} \mathrm{~km}^{-2} \mathrm{yr}^{-1}$ in 2010, showing a decreasing trend. The study demonstrates a varied contribution of different $\mathrm{N}$ inputs to river DIN yields during the period 1995-2010. Biological N fixation contributes about $73.3 \%$ of DIN yields before 2005, but the contribution decreases substantially to $28.4 \%$ in 2010. Chemical N fertilizer application and animal manure $\mathrm{N}$ inputs together contribute $12.6 \%$ of the river DIN yields, while atmospheric $\mathrm{N}$ deposition contributes an average of $5.5 \%$ of DIN yields in the period 1995-2010. Sewage N inputs contributes an average of $5.2 \%$ of DIN yields over the period 1995-2005, while the contribution increases remarkably to $69.7 \%$ in 2010. The trophic state index (TSI) of Lake Poyang agrees well with modeled DIN yields from the Ganjiang River over the whole study period.

Conclusions: $\mathrm{N}$ inputs from nonpoint sources are approximately 10-54 times that from point sources. Almost all the diffuse DIN inputs were retained in the watershed before entering the lake Poyang. While about half of sewage N inputs were input to Lake Poyang as DIN from the Ganjiang River. Modeled DIN yield from Ganjiang River decreased after 2005 significantly, providing evidence for the recovering capacity of watersheds to retain DIN as inputs decrease as a direct result of human activities. The study also demonstrates a varied contribution of different $\mathrm{N}$ inputs to river DIN yields during the study period. The authors also point out that more attention should be kept on reducing sewage $\mathrm{N}$ discharge to Lake Poyang in the background of global warming.
\end{abstract}

Keywords: Dissolved inorganic nitrogen; Water environment; Ganjiang River; Lake Poyang basin; Global NEWS-DIN model; China

\footnotetext{
* Correspondence: xyli@niglas.ac.cn

Key Laboratory of Watershed Geographic Sciences, Nanjing Institute of

Geography and Limnology, Chinese Academy of Sciences, Nanjing 210008,

China
} 


\section{Background}

The global mean temperature has risen by $0.85{ }^{\circ} \mathrm{C}$ from 1880 to 2012, and this increase may even accelerate in the future (IPCC 2014). The global warming can significantly alter the regional hydrology and inflows to lake ecosystems (IPCC 2014). The changes in hydrological cycles caused by climate change, including precipitation, evapotranspiration, soil moisture, river flow, and groundwater, strongly influences environmental quality, aquatic ecosystem productivity, and chemical exports from the watersheds to lakes (Catherine et al. 2003; Mortsch et al., 2003). In the 1980s, the spring diatom bloom in Lake Erken in Sweden $\left(59^{\circ} 25^{\prime} \mathrm{N}, 18^{\circ} 15^{\prime} \mathrm{E}\right)$ appeared earlier than in the 1970s and there was a five-fold increase in the summer abundance of the blue-green algae Gloeotrichia (Weyhenmeyer et al., 1999). Serious cyanobacterial blooms were reported in a number of European lakes during the warm summer of 2003 and there was evidence to suggest that some species have already extended their geographical range (Wiedner et al., 2007). By using nighttime thermal infrared imagery, Schneider and Hook (2010) reported that the surface temperatures of large inland water bodies worldwide have been rapidly warming since 1985 with an average rate of $0.045 \pm 0.011{ }^{\circ} \mathrm{C} \mathrm{yr}^{-1}$ and rates as high as $0.10 \pm 0.01{ }^{\circ} \mathrm{C} \mathrm{yr}^{-1}$. Combing historical and paleolimnological data, Catherine et al. (2003) pointed out that climate change has contributed to diminish productivity in Lake Tanganyika over the past 80 years. The observed global climate change was responsible for an increased contribution of diffuse nutrient losses to the total nutrient load in water bodies (Bouraoui et al., 2004).

Rivers play a key role in linking between terrestrial and aquatic ecosystems. A large amount of $\mathrm{N}$ pollutants is transported through rivers to water bodies. As the most abundant and bioavailable form of N, Dissolved inorganic nitrogen (DIN) attracts more attention of scientists in recent studies (Dumont et al. 2005; Yan et al. 2010). It is reported that DIN yields from the Yangtze River to estuary increased evidently from 1970 to 2003 (Yan et al. 2010). The authors suggested that anthropogenically enhanced $\mathrm{N}$ inputs dominate river DIN yields in the basin. However, much uncertainty remains in the quantification of the impact of human activities on river DIN export (He et al., 2009, 2011).

Lake Poyang, located at the southern bank of the middle and lower reaches of the Yangtze River, is regarded as the largest freshwater lake in China. The water quality of Lake Poyang shows a decreasing trend in past 4 decades. According to the surface water environmental quality standard in China (GB3838-2002), the water quality is at Level I if the total nitrogen concentration (TN) of lake water is below $0.2 \mathrm{mg} \mathrm{L}^{-1}$, it is at Level
II if $0.2<\mathrm{TN} \leq 0.5 \mathrm{mg} \mathrm{L}^{-1}$, at Level III if $0.5<\mathrm{TN} \leq$ $1.0 \mathrm{mg} \mathrm{L}^{-1}$, at Level VI if $1.0<\mathrm{TN} \leq 1.5 \mathrm{mg} \mathrm{L}^{-1}$, at Level $\mathrm{V}$ if $1.5<\mathrm{TN} \leq 2.0 \mathrm{mg} \mathrm{L}^{-1}$, and at worse than Level V if TN $>2.0 \mathrm{mg} \mathrm{L}^{-1}$. The Water quality of lake Poyang was at Level I in the early 1980s and at Level II III in the 1990s (Liu, 1987; Wan and Jiang, 2005). When it comes to the $21^{\text {st }}$ Century, the water quality of Lake Poyang deteriorated continuously. It changed from Grade II III in 2001 to Grade IV V in 2009 (Wu et al., 2011). The deterioration of lake water quality has been a threat to the survival of aquatic organisms. The estimated population of Siberian Crane in the Lake Poyang region decreased from 2760 in 2006 to 2495 in 2011 (Barter et al., 2006; Jia et al., 2013).The annual average dry season in the 2000s is 175 days, which is longer than that in any previous decades. Especially in recent years, extreme drought events in Poyang Lake basin occurred frequently (Liu et al., 2014). Many researchers pointed out the damage of rainfall reduction in the Lake Poyang basin (Min and Zhan, 2012; Liu et al., 2014). In 2011, Lake Poyang suffered from a terrible drought, leading to serious degradation of lake wetlands ecosystem. The lake area in the dry seasons was only 10 percent of that in the wet seasons. Because of drought, the number of fishes decreased sharply causing enormous economic losses to fishermen. Due to the sharp decline in water level of the lake, the wintering migratory birds to Lake Poyang wetland were facing feeding difficulty. Therefore, the number of migratory waterbirds to Lake Poyang in 2011 winter clearly decreased (Wang et al., 2013). The catastrophic flood during July-August 1998 in the Yangtze River basin significantly reduced density and biomass of Potamogeton malaianus, Vallsineria spiralis and Carer cinerascens (Cui et al., 2000). There have been large amounts of research on hydrology, biology and water environment of Lake Poyang in recent years (Ye et al. 2013; Wang et al., 2013). However, there is little data available for tracing the trajectory of DIN flux in the basin over a relative long period.

This study is the first to model the exports of DIN from the Ganjiang River to Lake Poyang in the period 1995-2010 based on quantitative analysis of N cycling. Findings from this study should provide a better understanding of the $\mathrm{N}$ cycling under changing human pressures and climate change.

\section{Methods}

\section{Study area}

The Ganjiang River watershed is located in the south of Lake Poyang Basin, Jiangxi, China (Fig. 1). The Ganjiang River is the largest river of Lake Poyang basin and flows into Lake Poyang and the Yangtze River. The sampling 

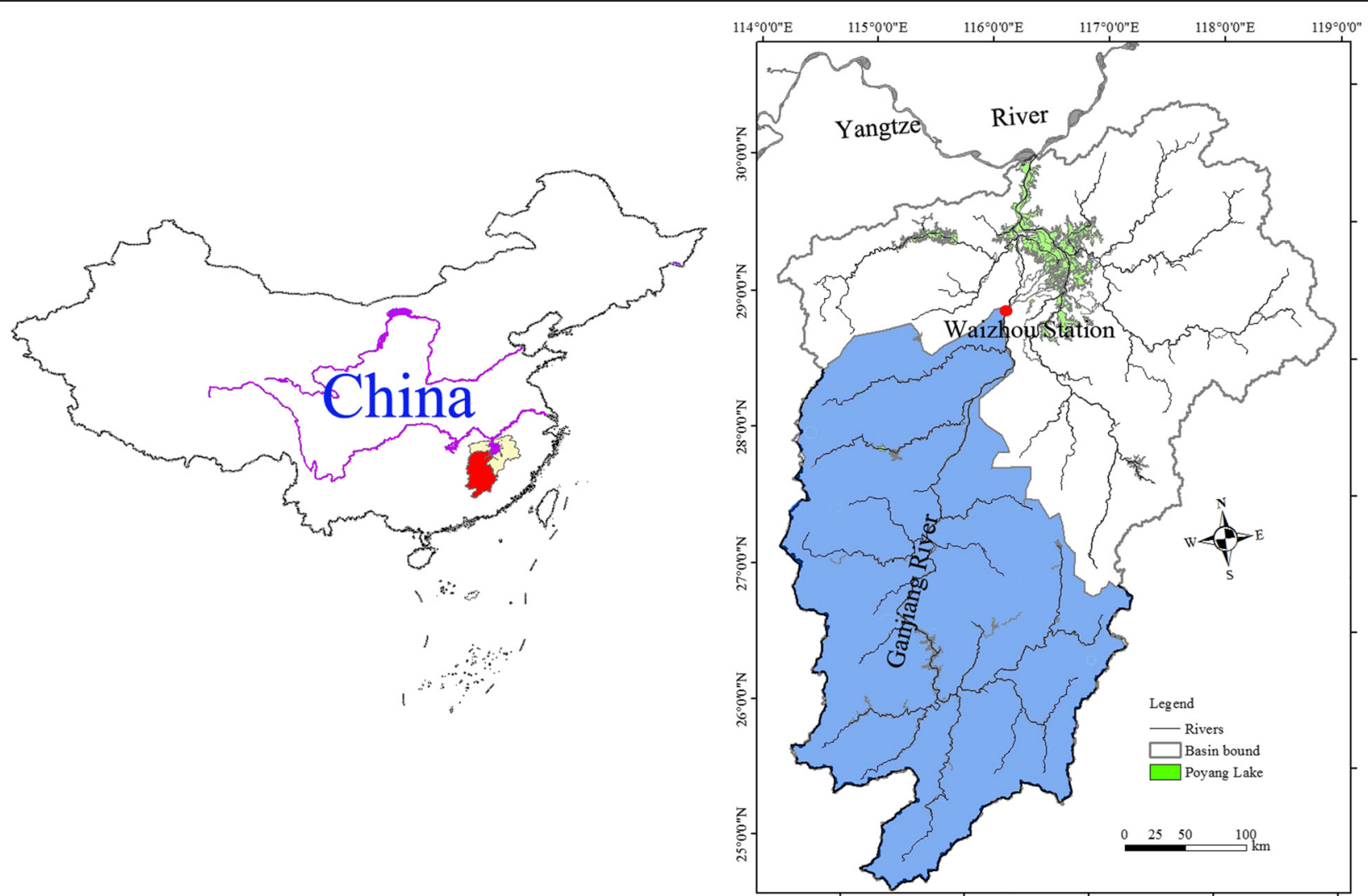

Fig. 1 Location of Ganjiang River watershed in the Poyang Lake Basin, China

location for this study was Waizhou gauging station located at the mouth of Ganjiang River (Fig. 1). The Ganjiang River drains a total area of $11.23 \times 10^{4} \mathrm{~km}^{2}$ and has an average annual discharge of $686.5 \times 10^{8} \mathrm{~m}^{3}$ per year at the sampling location. The Ganjiang River watershed belongs to a subtropical wet climate zone with an annual mean temperature of $17.5{ }^{\circ} \mathrm{C}$ and annual mean precipitation of $1680 \mathrm{~mm}$ (Ye et al., 2013). The annual mean temperature clearly increased (blue circle, Fig. 2), while the annual mean precipitation varied slightly in recent 20 years (red square, Fig. 2).

\section{Riverine DIN flux estimate}

To estimate annual DIN export from the Ganjiang River in 1995-2010, the widely applied global NEWS-DIN model was utilized (Dumont et al. 2005; Mayorga et al. 2010).

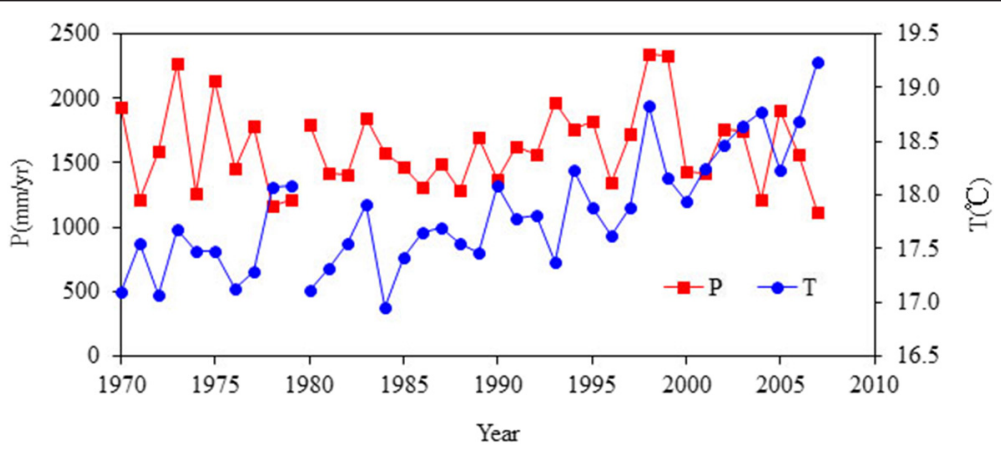

Fig. 2 Historical trends for precipitation (P) and Temperature (T) in the Ganjiang catchment over the 1980-2007 period 
Table 1 Parameters Used in the Global NEWS-DIN Model

\begin{tabular}{|c|c|c|c|}
\hline Model Parts & Parameters & Units & Parameters Explanation \\
\hline \multirow[t]{3}{*}{ Hydrology coefficients } & Runoff & $\mathrm{m} y \mathrm{r}-1$ & Water runoff \\
\hline & $Q_{\text {rem }}$ & $0-1$ & Fraction of consumptively use water removed from the river \\
\hline & $D_{\text {din }}$ & $0-1$ & Fraction of $\mathrm{N}$ retained by reservoirs \\
\hline \multirow[t]{4}{*}{ Point sources } & GDP & U.S.\$ indiv. ${ }^{-1}$ & Gross domestic product as purchasing-power parity \\
\hline & Pop ${ }_{\text {Dens }}$ & indiv. $\mathrm{km}^{-2}$ & Population density \\
\hline & $\mathrm{R}$ & $0-1$ & Fraction of $\mathrm{N}$ removed by sewage treatment \\
\hline & । & $\%$ & $\%$ of population connected to sewage system \\
\hline \multirow[t]{7}{*}{ Diffuse sources } & $\mathrm{TN}_{\mathrm{fe}}$ & 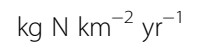 & TN applied as fertilizer \\
\hline & $\mathrm{TN}_{\mathrm{ma}}$ & $\mathrm{kg} \mathrm{N} \mathrm{km}^{-2} \mathrm{yr}^{-1}$ & TN applied as animal manure \\
\hline & $\mathrm{TN}_{\mathrm{fix}}$ & $\mathrm{kg} \mathrm{N} \mathrm{km}{ }^{-2} \mathrm{yr}^{-1}$ & TN fixed by natural and agricultural fixation \\
\hline & $\mathrm{TN}_{\text {dep }}$ & $\mathrm{kg} \mathrm{N} \mathrm{km}^{-2} \mathrm{yr}^{-1}$ & TN deposited via atmospheric deposition for Waizhou Station drainage area \\
\hline & $T N_{\exp }$ & $\mathrm{kg} \mathrm{N} \mathrm{km}^{-2} \mathrm{yr}^{-1}$ & TN exported from the basin as crop harvest \\
\hline & $\mathrm{FE}_{\mathrm{ws}}$ & $0-1$ & Fraction of $\mathrm{N}$ exported from landscape to the rivers as DIN \\
\hline & RSD & $0-1$ & The ratio of watershed $N$ surplus against $N$ input \\
\hline
\end{tabular}

\section{NEWS-DIN model}

Definitions of all the parameters used in this model are given in Table 1. NEWS-DIN can be summarized as follows:

$$
D I N_{\text {yield }}=F E_{\text {riv }}\left(D I N_{\text {sew }}+F E_{W S} \bullet T N_{\text {diff }}\right)
$$

Where $D I N_{\text {yield }}$ is modeled annual DIN load per river basin; $F E_{r i v}$ is a river export fraction representing the fraction of total point and nonpoint DIN inputs to the river that exported as DIN $(0-1) ; D I N_{\text {sew }}$ is DIN from sewage point sources to rivers; $F E_{W S}$ is a watershed export fraction representing the fraction of total nitrogen (TN) from nonpoint sources in the watershed that leaches to rivers as DIN; $T N_{\text {diff }}$ is net total nitrogen from nonpoint sources that is mobilized from the watershed soils and sediments. Almost all basin-scale $\mathrm{N}$ input and river export terms (including $D I N_{\text {yield }}, D I N_{\text {sew }}$, and $\left.T N_{\text {diff }}\right)$ are expressed as total $\mathrm{N}$ mass load per year normalized by basin area at Waizhou Station (WZS), expressed in $\mathrm{kg} \mathrm{N} \mathrm{km}^{-2} \mathrm{yr}^{-1}$.

\section{Point source (DIN sew $_{\text {) }}$}

As described by Dumont et al. (2005), an indirect approach was used to calculate total $\mathrm{N}$ input into rivers from point sources $\left(T N_{\text {sew }}, \mathrm{kg} \mathrm{N} \mathrm{km}^{-2} \mathrm{yr}^{-1}\right)$ as

$$
T N_{\text {sew }}=\left(1-T N_{\text {frem }}\right) \cdot I \cdot\left(H \cdot E_{N}\right)
$$

In which $E_{N}$ is the per capita $\mathrm{N}$ emission as human waste, $H$ is population density, $I$ is the fraction of the population that is connected to a sewage system, and $T N_{\text {frem }}$ is the fraction of TN in sewage influent that is removed by wastewater treatment. $E_{N}$ is estimated using an empirical function of per capita gross domestic product (GDP) that is based largely on protein consumption; this relationship was updated by Van Drecht et al. (2009) to use per-purchasing parity GDP (GDP $\left.P_{p p p}\right)$ rather than market-exchange-rate GDP $\left(G D P_{\text {mer }}\right)$ as originally formulated (Dumont et al., 2005; Van Drecht et al., 2003). Data on provincial $G D P_{\text {mer }}$ and population (including urban and rural) come from Jiangxi Statistical Yearbooks (Jiangxi National Bureau of Statistics, 19962010); basin-aggregated $G D P_{\text {mer }}$ was converted to $G D P_{p p p}$ using the annual ratio of national $G D P_{\text {mer }}$ to $G D P_{p p p}$ values for Jiangxi (World Bank, 2001). The fraction of total population connected to sewage systems (I) is estimated as the ratio of urban and total population living in the basin (\%).

\section{Diffuse source $\left(T N_{\text {diff }}\right)$}

The total amount of diffuse source nitrogen that is mobilized annually $\left(T N_{\text {diff }}\right)$ is estimated as

$$
\begin{aligned}
T N_{\text {diff }} & =T N_{f e}+T N_{m a}+T N_{f i x} \\
& +T N_{\text {dep }}-T N_{\text {exp }}
\end{aligned}
$$

All terms are in $\mathrm{kg} \mathrm{N} \mathrm{km}^{-2} \mathrm{yr}^{-1}$; the definition of each term is given by Yan et al. (2010) and Li et al., (2011).

$T N_{f e}$ is defined as the ratio of yearly $\mathrm{N}$ fertilizer application and basin area. Data of $\mathrm{N}$ fertilizer application and forms in the basin are available in the Jiangxi Statistical Yearbooks (Jiangxi Statistical bureau, 1996-2010). The data of all $\mathrm{N}$ fertilizer forms were converted into element $\mathrm{N}$ to estimate $\mathrm{N}$ fertilizer input.

$T N_{m a}$ is calculated as animal manure $\mathrm{N}$ input divided by WZS drainage area. Animal manure $\mathrm{N}$ input is the product of yearly animal populations and $\mathrm{N}$ excretion rates by animal category. Animal categories summarized 
in this article include pigs, cattle, sheep, horses, and poultry. Data of these animal populations comes from Jiangxi Statistical Yearbooks (Jiangxi Statistical bureau, 1996-2010). The mean stock of animals by category includes standing livestock animals at the end of a year and animals slew during that year. Considering the fact that slain animals no longer produce manure, the number of slain animals is corrected with the factor $\mathrm{c}$ $(c=0.542)$, representing the time during which slain animals were part of the living stock (Yan et al., 2010).

$\mathrm{N}_{2}$ fixation $\left(T N_{f i x}\right)$ refers to the sum of symbiotic $\mathrm{N}$ fixation by cultivation of $\mathrm{N}$ fixation by microorganisms in both managed and natural ecosystems. $\mathrm{N}$ fixation input is estimated by multiplying the rate of fixation $(\mathrm{kg} \mathrm{N}$ $\mathrm{ha}^{-1}$ ) for each natural ecosystem by its area within the basin. The legume crops are grouped as soybeans, peanuts, and green-manure crops in the basin. Nonlegume crops include all the other vegetation except the legume crops and rice. The differences between the natural and manmade forest (grassland) are ignored in this article. The $\mathrm{N}$ fixation rates are given by Yan et al. (2003).

Atmospheric $\mathrm{N}$ deposition rates $\left(T N_{\text {dep }}\right)$ (including dry and wet deposition of $\mathrm{NH}_{3}$ and $\mathrm{NO}_{\mathrm{y}}$ ) of forestland and farmland in Ganjiang River watershed were calculated according to the research obtained by others based on monitoring (Fan et al., 2007; Lv and Tian, 2007; Wang et al., 2008; Yang et al., 2009; Li et al., 2011). Since atmospheric $\mathrm{NH}_{3}$ sinks to the ground in a short distance, only atmospheric $\mathrm{NO}_{\mathrm{y}}$ deposition is considered in this study. $T N_{\text {dep }}$ is estimated as

$$
T N_{\text {dep }}=F_{N O y} \bullet A_{i}
$$

Where, $T N_{\text {dep }}$ is atmospheric $\mathrm{NO}_{\mathrm{y}}^{-} \mathrm{N}$ deposition, $\mathrm{kg}$; $F_{N O y}$ is the flux of atmospheric $\mathrm{NO}_{\mathrm{y}}^{-} \mathrm{N}$ deposition, kg N $\mathrm{ha}^{-1} ; A_{i}$ is land area in ha; the parameter of $i$ represents forestland and farmland.

\section{Watershed export}

The watershed export fraction $\left(F E_{W S}\right)$ represents an aggregate of all processes leading to retention of diffuse $\mathrm{N}$ inputs during transport to the surface water (Dumont et al., 2005). It is defined as

$$
F E_{W S}=e \cdot R
$$

Where $R$ is runoff $\left(\mathrm{m} \mathrm{yr}^{-1}\right)$ and $e$ is set at 0.94 , based on a global calibration described by Mayorga et al. (2010).

\section{River system retention}

DIN retention terms in river systems include estimates for denitrification, removal via consumptive water use, and loss in reservoirs. The river export term $\left(F E_{r i v}\right)$ is then calculated as the multiplication of the export fractions corresponding to each of these terms. Full details are presented by Dumont et al. (2005), Mayorga et al. (2010) and Yan et al. (2010).

$$
F E_{\text {riv }}=(1-D) \cdot\left(1-Q_{\text {rem }}\right) \cdot\left(1-L_{d e n}\right)
$$

DIN retention in reservoirs $(D)$ within a watershed is estimated as a function of characteristics for each reservoir: mean reservoir depth $(m)$, discharge intercepted by dams $\left(\mathrm{km}^{-3} \mathrm{yr}^{-1}\right)$, and change in water residence time due to the construction of reservoirs (days).

$$
D=\frac{1}{Q} \cdot\left[\sum_{i=1}^{n} 0.8845 \cdot\left(\frac{D E P T i}{R t i}\right)^{-0.3677}\right] \cdot Q_{i}
$$

Where $D E P T_{i}$ is reservoir depth, $\mathrm{m}, R_{t i}$ is water residence time (years), and $i$ is the reservoir identification number within a watershed $(\mathrm{i}=1,2, \ldots, \mathrm{n}) . Q_{i}$ is the discharge intercepted by dam $i, \mathrm{~km}^{3} \mathrm{yr}^{-1}$; $Q$ is the total discharge, $\mathrm{km}^{3} \mathrm{yr}^{-1}$. Data of the variables and completion years for 5 artificial reservoirs in Ganjiang River watershed were compiled to calculate D.

$$
Q_{\text {rem }}=\frac{Q_{\text {irr }}+Q_{\text {div }}}{Q_{\text {nat }}}
$$

\section{Source contributions}

The contributions of sewage inputs and each diffuse source to DIN yields at WZS are estimated by isolating the respective terms in $\mathrm{Eq}(1)$. The sewage contribution is calculated as the point-source DIN input to rivers $\left(D I N_{\text {sew }}\right.$ in $\left.\mathrm{Eq}(1)\right)$ multiplied by the river export term $\left(F E_{r i v}\right)$ (Yan et al, 2010). The contribution of each diffuse source to DIN yield is calculate as

$$
\begin{aligned}
D I N_{f i x} \% & =F E_{r i v} \cdot F E_{\text {ws-fit }} \cdot T N_{f i x} \bullet 100 \\
\cdot & \cdot\left[1-0.23 \cdot T N_{\text {exp }} /\left(T N_{f e}+T N_{m a}+0.23 \cdot T N_{f i x}\right)\right] / D I N_{\text {yield }}
\end{aligned}
$$

$$
\begin{aligned}
& D I N_{f e} \%=F E_{r i v} \cdot F E_{w s-f i t} \cdot T N_{f e} \bullet 100 \\
& \cdot\left[1-T N_{\text {exp }} /\left(T N_{f e}+T N_{m a}+0.23 \cdot T N_{f i x}\right)\right] / D I N_{\text {yield }} \\
& D I N_{m a} \%=F E_{r i v} \cdot F E_{w s-f i t} \cdot T N_{m a} \cdot 100 \\
& \cdot\left[1-T N_{\text {exp }} /\left(T N_{f e}+T N_{m a}+0.23 \cdot T N_{f i x}\right)\right] / D I N_{\text {yield }} \\
& D I N_{d e p} \%=F E_{r i v} \bullet F E_{w s-f i t} \bullet T N_{d e p} \bullet 100 \\
& \cdot\left[1-T N_{\text {exp }} /\left(T N_{f e}+T N_{m a}+0.23 \cdot T N_{f i x}\right)\right] / D I N_{\text {yield }}
\end{aligned}
$$

\section{Measured DIN export from watershed}

Measured DIN yield was obtained as follows: 


$$
D I N_{\text {mea }}=Q \cdot C / A
$$

$D I N_{\text {mea }}$ is measured DIN yields at WZS, $\mathrm{kg} \mathrm{N} \mathrm{km}^{-2}$ $\mathrm{yr}^{-1} ; Q$ is measured discharge at WZS, $10^{7} \mathrm{~m}^{3} \mathrm{yr}^{-1} ; C$ is measured DIN (referring to $\mathrm{NO}_{3}^{-}-\mathrm{N}$ and $\mathrm{NH}_{4}^{+}-\mathrm{N}$ ) concentration at WZS, $\mathrm{mg} \mathrm{L}^{-1} ; A$ is watershed area, $\mathrm{km}^{2}$.

River water samples were collected once every two months ( $\mathrm{n}=96$ sampling times total) at Waizhou gauging station from 1995 to 2010 (Fig. 1) by Hydrology Bureau of Jiangxi Province. The concentration of $\mathrm{NO}_{3}^{-}$in water sample was determined by the spectrophotometric phenol disulfonic acid method; $\mathrm{NH}_{4}^{+}$by spectrophotometric salicylic acid method (Duan et al., 2000). Data for daily river discharge at Waizhou station and daily precipitation and temperature in Nanchang city were obtained from the Hydrology Bureau of Jiangxi Province and China Meteorological Data Sharing Service System, respectively.

\section{Model analysis}

Paired Samples T Test Method was applied to test whether the difference between the modeled and measured values was significant at the level of $P=0.05$ by using the software of IBM SPSS 19.0. A significant difference would indicate the model results did not agree well with the measured values. In that case, the model would have needed modification. If not, the global NEWS-DIN model could be applied in the Ganjiang River watershed to model the DIN export. Model Error $(M E)(\%)$, was calculated as

$$
M E=(\text { Mod }-M e a) \cdot 100 / \text { Mea }
$$

Where Mod is modeled DIN export and Mea is measured DIN export for the watershed.

\section{Trophic State Index (TSI)}

Nitrogen content is one of the primary determinants of water body's trophic state index (TSI). Nutrients such as nitrogen and phosphorus tend to be limiting resources in standing water bodies, so increased nitrogen concentrations tend to result in increased plant growth, followed by corollary increases in subsequent trophic levels. TSI is calculated according to the formula,

$$
\operatorname{TSI}\left(\sum\right)=\sum W_{j} \cdot T S I_{(j)}
$$

Where, TSI is the comprehensive trophic state index of lakes. $W_{j}$ is the relative weights of trophic state index of parameter $j . \operatorname{TSI}_{(j)}$ represents the trophic state index of parameter $j$.

Annual data of TSI of Lake Poyang in the period 1995-2010 were obtained from Water Resources Bulletin of Jiangxi Province (http://www.jxsl.gov.cn/slgb/ szygb/index.html).

\section{Data resources}

Data on social economic development, including GDP, population, urbanization rate, etc. and data of agricultural fertilization intensity, numbers of domestic animals and planting area of different crops were derived from the Statistical yearbooks of Jiangxi Province (1996-2011). Data of annual wastewater discharge were derived from Water Resources Bulletin of Jiangxi Province (1999-2011).

\section{Results}

\section{Nonpoint and point sources $\mathbf{N}$ inputs}

Based on statistical data, watershed $\mathrm{N}$ budgets were calculated by using watershed $\mathrm{N}$ balance model proposed by OECD (2001). It shows that the net $\mathrm{N}$ inputs from diffuse sources $\left(T N_{\text {diff }}\right)$ are 10-54 times that of sewage $\mathrm{N}$ inputs over the period 1995-2010. Diffuse sources $\mathrm{N}$ inputs decrease from $4400 \mathrm{~kg} \mathrm{~N}$ $\mathrm{km}^{-2} \mathrm{yr}^{-1}$ in 1995 to $3300 \mathrm{~kg} \mathrm{~N} \mathrm{~km} \mathrm{yr}^{-1}$ in 2010 (Fig. 3). Among the diffuse $\mathrm{N}$ sources, biological $\mathrm{N}$ fixation is the largest contributor, accounting for about $45.4 \% \sim 48.3 \%$ of total $\mathrm{N}$ inputs, showing a slightly variation over the period 1995-2010. Chemical N fertilizer application is the second largest contributor, accounting for about $26.0 \%-30.3 \%$ of total $\mathrm{N}$ inputs. Fertilizer $\mathrm{N}$ application decreases considerably from $55.9 \times 10^{7} \mathrm{~kg}$ in 1995 to $43.4 \times 10^{7} \mathrm{~kg}$ in 2010 over the period 1995-2010 (Fig. 3). Atmospheric $\mathrm{N}$ deposition and manure $\mathrm{N}$ inputs contribute altogether with $24.7 \%$ of total $\mathrm{N}$ inputs, showing a slightly variation over the period 1995-2010. Sewage N inputs increases remarkably from $82 \mathrm{~kg} \mathrm{~N} \mathrm{~km}^{-2} \mathrm{yr}^{-1}$ in 1995 to $321 \mathrm{~kg} \mathrm{~N} \mathrm{~km}^{-2} \mathrm{yr}^{-1}$ in 2010.

\section{Contribution of different $\mathrm{N}$ input sources}

The contributions of different $\mathrm{N}$ sources input to DIN yields in the Ganjiang River watershed for the period 1995-2010 were estimated (Fig. 4). Biological $\mathrm{N}$ fixation accounts for about $73.3 \%$ over the period 1995-2005, but after this interval it decreases quickly to $28.4 \%$ in 2010. Fertilizer $\mathrm{N}$ application was the second largest contributor to DIN yield; it accounts for about $11.7 \%$ of DIN yields over the period 19952005. After this period it decreased sharply to $1.2 \%$ in 2010. Manure $\mathrm{N}$ and atmospheric $\mathrm{N}$ input together account for about $10 \%$ of DIN yields in the period 1995-2005, but they both decreased significantly to smaller than $1 \%$ in 2010 . The percentage of sewage $\mathrm{N}$ input against DIN yields varies substantially. It accounts for about $5 \%$ over the period 1995-2005, but after this interval it increases quickly to $69.7 \%$ in 2010. For all $\mathrm{N}$ input sources, it indicates that biological $\mathrm{N}$ fixation has dominated $\mathrm{N}$ inputs over the period 1995-2007, but after that it was exceeded by sewage $\mathrm{N}$ input gradually (Fig. 4). 


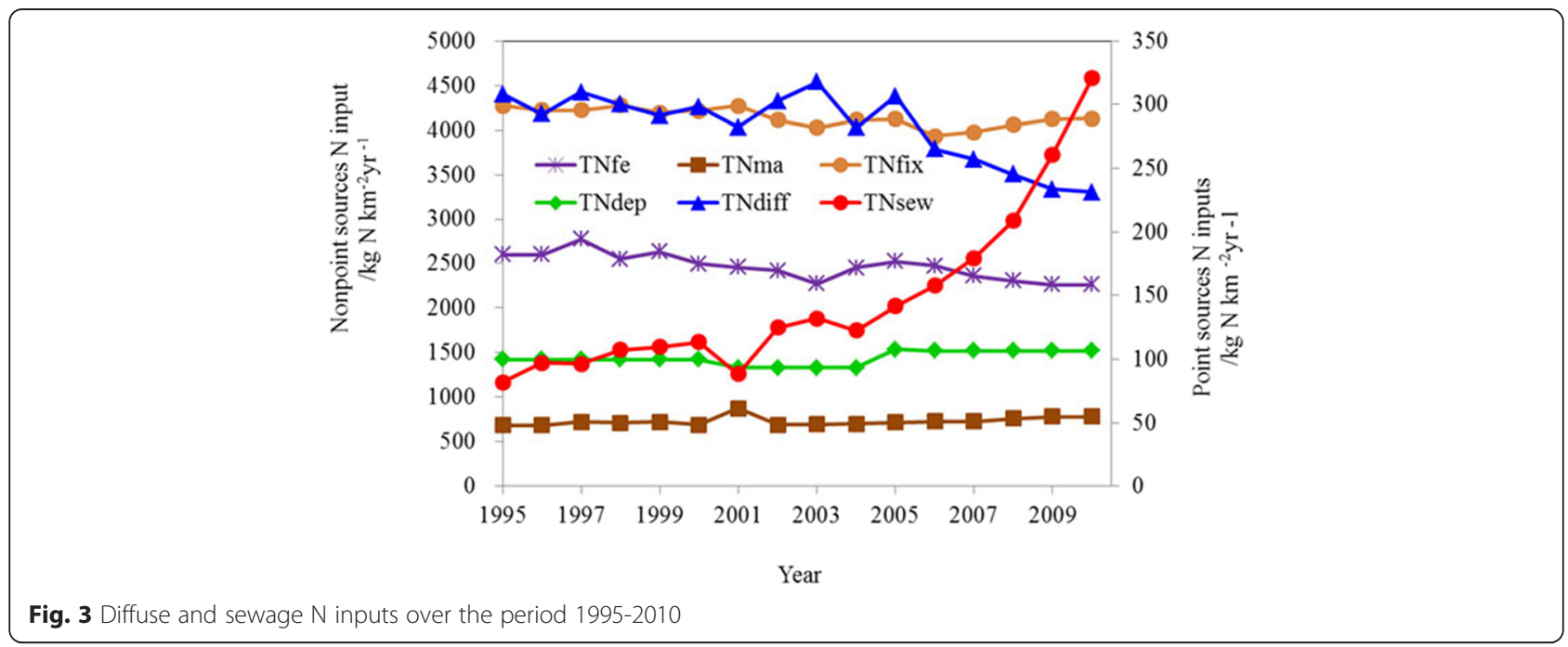

Sewage $\mathrm{N}$ inputs have been the biggest contributor to DIN yields for Ganjiang River since 2008.

\section{Diffuse and sewage DIN inputs changes}

As shown in Fig. 5, $\mathrm{N}$ inputs from nonpoint sources are much higher than those from point sources. The former are approximately 10-54 times the later. But as for DIN inputs, nonpoint DIN inputs decrease continuously especially after the year 2005. It decreases to $68.3 \mathrm{~kg} \mathrm{~N} \mathrm{~km}^{-2} \mathrm{yr}^{-1}$ in 2010. Sewage DIN inputs increase continuously over the period 19952010. It increases from $40.0 \mathrm{~kg} \mathrm{~N} \mathrm{~km} \mathrm{yr}^{-2}$ in 1995 to $156.8 \mathrm{~kg} \mathrm{~N} \mathrm{~km} \mathrm{yr}^{-1}$ in 2010, showing a relative consistent changing trend with sewage $\mathrm{TN}$ input. The ratio of DIN and total $\mathrm{N}$ inputs from nonpoint sources varies from $2.1 \%$ to $25.5 \%$ in the period 1995-2010. The ratio of DIN and total $\mathrm{N}$ inputs from point sources is about $48.8 \%$. It indicates that almost all the diffuse DIN inputs were retained in the watershed before entering the Lake Poyang. While about half of sewage $\mathrm{N}$ inputs were input to Lake Poyang as DIN from Ganjiang River.

\section{Changes of Trophic State Index (TSI) of Lake Poyang}

As shown in Fig. 6, we can see that TSI of Lake Poyang changed between 37 and 49. It decreased from 42 to 39 in 1995-1999, and it increased continuously to 49 in 2005, before decreasing to 44 in 2010 . The valley value occurred in 1998, 1999, 2000 and 2002, indicating a strong dilution effect in these flood years. The value of TSI decreases remarkably after 2005, which agrees well with the modeled and observed DIN export from the Ganjiang River.

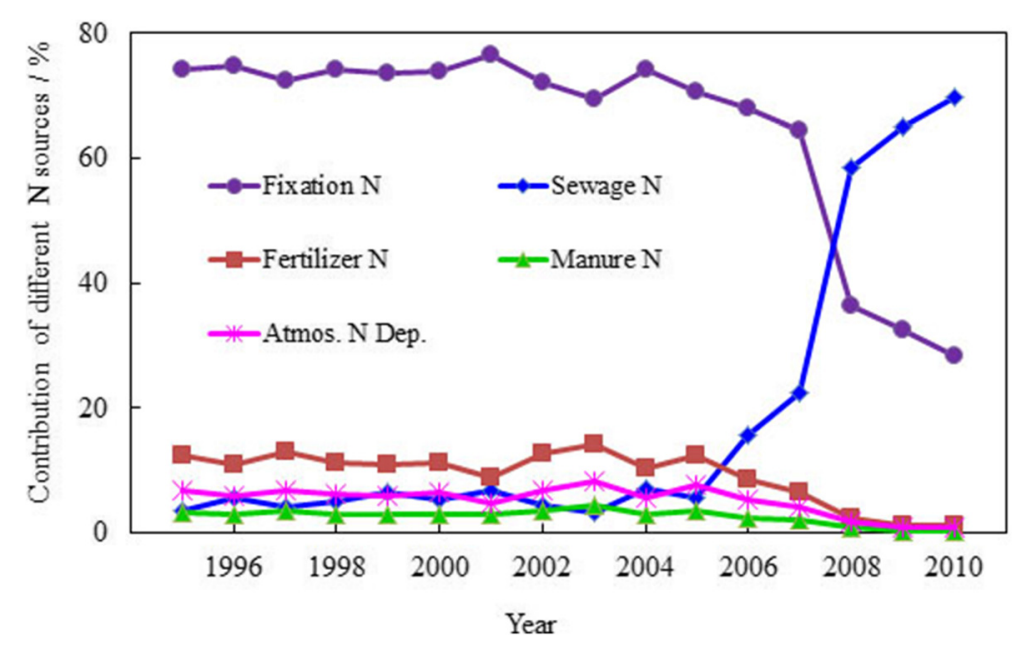

Fig. 4 Contributions of different N input sources to river DIN yields in the Ganjiang River watershed during the period 1995-2010 


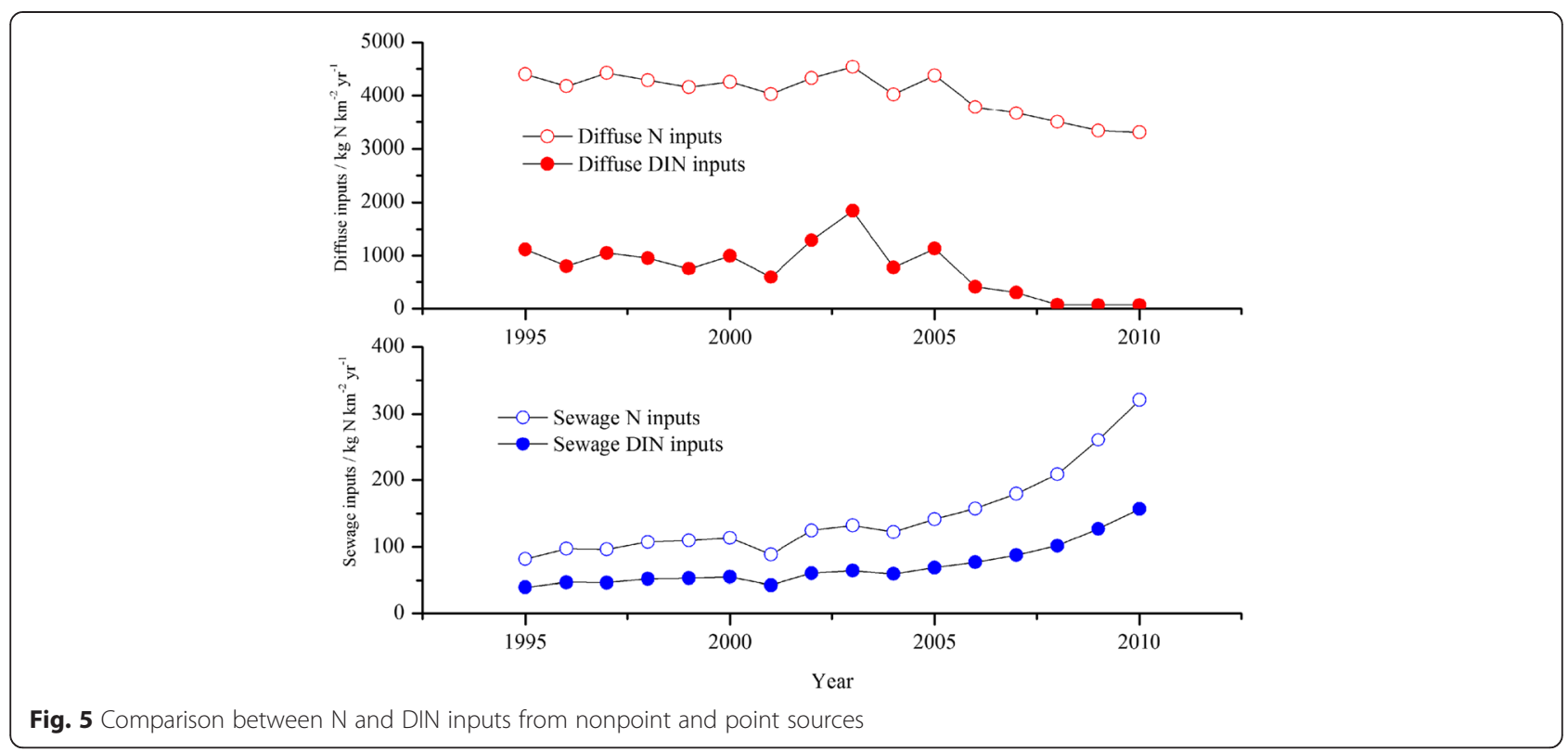

\section{Discussion}

\section{Reduction of nonpoint $\mathrm{N}$ sources inputs}

During 1995-2010, the $\mathrm{N}$ fertilizer application in the watershed decreases significantly. The rapid decrease of $\mathrm{N}$ fertilizer application could be attributed to natural disasters and reduction of cropland. In the summers of 1998 and 2002, the Yangtze River basin suffered from flood disasters, which severely affected the agricultural production in Jiangxi Province. The fertilizer N application had declined since 1998. In Jiangxi Province, the policy of returning farmland to forest was carried out continuously in 2001-2003. About $13.3 \times 10^{4}$ ha and $21.3 \times 10^{4}$ ha farmland were returned to forestland in 2002 and 2003, respectively, covering over 60 counties throughout the province. Accordingly, the fertilizer $\mathrm{N}$ application decreased sharply. The lowest value of fertilizer $\mathrm{N}$ application occurred in 2003. After that the fertilizer $\mathrm{N}$ application increased to meet people's need

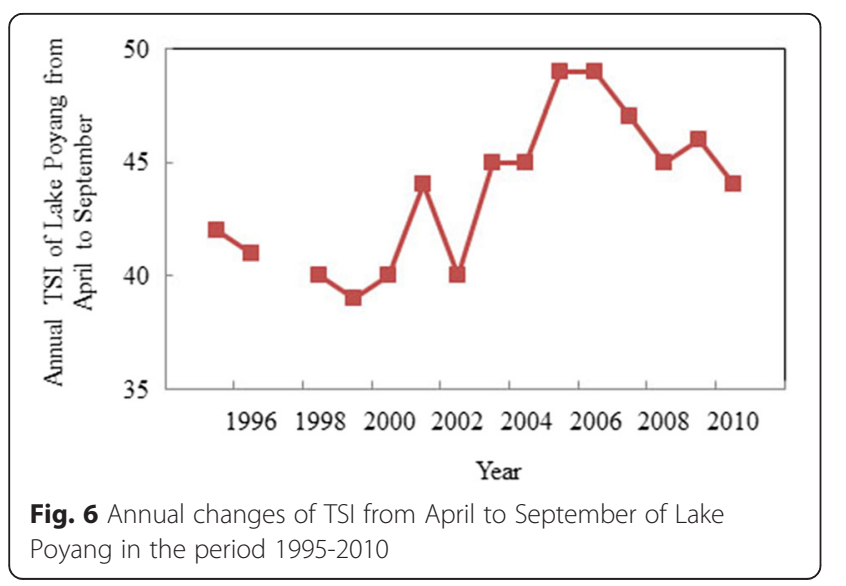

for food in the next two following years. Accordingly, TN export by harvesting decreased remarkably in 20012003 (Fig. 3). After 2005, with the acceleration of industrialization process, more and more farmers moved to cities to live and work. Due to the lack of labor force in the countryside and the reduction of farmland, inputs from fertilizer $\mathrm{N}$ application decreased year by year.

Some advanced production technology was applied in agriculture and some excellent crop varieties were promoted to increase crop yields, leading to the growth of $\mathrm{N}$ export by harvesting. More than half of $\mathrm{N}$ was exported by harvesting on average during the period 1995-2010 in the Ganjiang River watershed. Due to the decrease of anthropogenic $\mathrm{N}$ inputs and growth of $\mathrm{N}$ export by harvesting, the net $\mathrm{N}$ surplus in agriculture decreased remarkably in the period 1995-2010.

\section{Increase of sewage $\mathbf{N}$ input driven by urbanization}

The economy in the Ganjiang River watershed has quickly developed in the period 1995-2010. The gross domestic product was $4.6 \times 10^{10} \$(1 \$=6.8 \mathrm{RMB})$ in 2010 , with an increase of about seven times from that in 1995. In 1995-2010, the total number of population increased from $1.65 \times 10^{7}$ in 1995 to $1.97 \times 10^{7}$ in 2010 , with an average annual growth rate of $1.2 \%$ (Jiangxi Statistical Yearbook 2011). The urbanization rate continuously increased from $17.2 \%$ in 1995 to $35 \%$ in 2010. The growth of population and urbanization process will undoubtedly lead to sharp increase of wastewater discharge. According to Statistical Bureau of Jiangxi Province (1996-2011), the wastewater discharge in the Ganjiang River watershed increased from $1.1 \times$ $10^{12} \mathrm{~kg}$ in 1995 to $3.1 \times 10^{12} \mathrm{~kg}$ in 2010 . Accordingly, 
sewage $\mathrm{N}$ inputs increased significantly from $6.8 \times 10^{6}$ $\mathrm{kg}$ in 1995 to $26.8 \times 10^{6} \mathrm{~kg}$ in 2010 . Although sewage treatment ratio increased significantly in recent years, $\mathrm{N}$ removal fractions were very low due to the lack of advanced treatment facilities. As a result, a large portion of untreated sewage was discharged directly into surface water, contributing to sewage $\mathrm{N}$ pollution in the estuary to Lake Poyang. Under the background of global warming, as the demand for water is increasing, sewage discharge from urban and rural areas will increase continuously. The contribution of sewage discharge to DIN yield for the Ganjiang River Watershed will continue to increase based on the Global NEWSDIN model.

\section{DIN yield decrease}

Rivers play an important role in delivering nutrients from landscape to water bodies. As the longest river in Lake Poyang basin, Ganjiang River transports a great deal of nutrients to lake, which affects the lake trophic status greatly. According to Yan et al. (2010), the fraction of $\mathrm{N}$ lost from landscape to rivers as DIN ( $\mathrm{FE}_{\mathrm{WS}}$ ) should increase over time along with the increasing input of newly nitrogen driven by human activities, and vice versa. The fluctuation of DIN yield in 1995-2005 indicates that anthropogenic $\mathrm{N}$ input is relatively steady. The decrease of DIN export for Ganjiang River in 2005-2010 reflects the decrease of $\mathrm{N}$ input and the enhancement of retaining DIN for landscape in the watershed.

Soils that contain high $\mathrm{N}$ levels can become a primary source of dissolved $\mathrm{N}$ in runoff, and thus contribute to the degradation of surface water quality (Edwards and Daniel 1993). The capacity to store $\mathrm{N}$ can ultimately become saturated as $\mathrm{N}$ inputs into the watershed increase beyond the requirements of the ecosystem. As the $\mathrm{N}$ saturation is reached, $\mathrm{N}$ retention within the watershed can be expected to decrease rapidly due to the inability of terrestrial ecosystems to utilize further $\mathrm{N}$ additions. Accordingly, the fraction of $\mathrm{N}$ lost from landscape to rivers as DIN should decrease over time following the decreasing $\mathrm{N}$ inputs driven by human activities. The forest has a strong ability to fix nitrogen. The Jiangxi Province government gave much importance to afforestation as its forest cover increased from $50 \%$ in 1995 to $63 \%$ in 2010. The forest ecosystem plays a vital role in improving the capacity of landscape to storing $\mathrm{N}$. In this article, $\mathrm{FE}_{\mathrm{ws}-\mathrm{fit}}$ (the fitted fraction of $\mathrm{N}$ lost from landscape to rivers as DIN) varied slightly in 19952005, while it decreased significantly in 2006-2010, providing evidence for the recovering capacity of watersheds to retain $\mathrm{N}$ as inputs decreased as a direct result of human activities.
Climate change Impacts on river runoff, nutrients flux and atmospheric $\mathrm{N}$ deposition

An increase in water temperature alters the rate of operation of some key chemical processes in water. Also, changes in intense precipitation events impact the rate at which materials are flushed to rivers and lakes, and changes in flow volumes affect dilution of loads (Kundzewicz et al. 2008). The average annual temperature in recent 5 years (2006-2010) is $0.5^{\circ} \mathrm{C}$ higher than that in 1995-2005. While the average annual precipitation in 2006-2010 is $215 \mathrm{~mm}$ lower than that in 1995-2005. The warming and drying climate reduces the water volumes in the watershed, and thus reduces the dilution capacity of Lake Poyang.

Key consequences of declining water quality due to climate change include increasing water withdrawals from low-quality sources; greater pollutant loads from diffuse sources due to heavy precipitation (via higher runoff and infiltration); water infrastructure malfunctioning during floods; and overloading the capacity of water and wastewater treatment plants during extreme rainfall (Kistemann et al., 2002). Recent studies show that climate plays a dominant role in changing basin hydrology and runoff in the Lake Poyang basin (Guo et al., 2008; Ye et al., 2013). The measured DIN yield is highest in the 1998 flood year, which indicates that the increase of precipitation, especially the increased frequency of summer storms is the main reason for the increase of runoff. Runoffs measured at most gauging stations in the Lake Poyang basin show increasing trends, but monthly variations are obviously different. The monthly variability of runoff may indicate a change of seasonal climate regime. The increase of annual runoff was primarily affected by climate change for the whole catchment (Ye et al., 2013). However, nowadays, little work has been conducted to quantify the effects of climate change on the water environment of Lake Poyang due to the lack of data on water quality in the basin.

The atmospheric $\mathrm{NO}_{\mathrm{y}}^{-} \mathrm{N}$ deposition mainly comes from coal combustion (Tian et al., 2001). Under the background of global warming, the rapid growth in energy consumption leads to the growth of $\mathrm{NO}_{y}$ emission in China (Tian and Hao, 2003; Wang et al., 2012). High emissions produce high deposition. Consequently, atmospheric $\mathrm{N}$ deposition has increased considerably over the past 16 years (Liu et al., 2013).

\section{Uncertainty analysis}

\section{DIN model performance}

Comparison of modeled versus measured DIN yields indicates that NEWS-DIN's predictive capacity is quite high, but varies from year to year. It shows that the differences between modeled and measured values are not significant at the level of $\mathrm{P}=0.05$ by using Paired Samples $\mathrm{T}$ Test method in the software of IBM SPSS 19.0, 


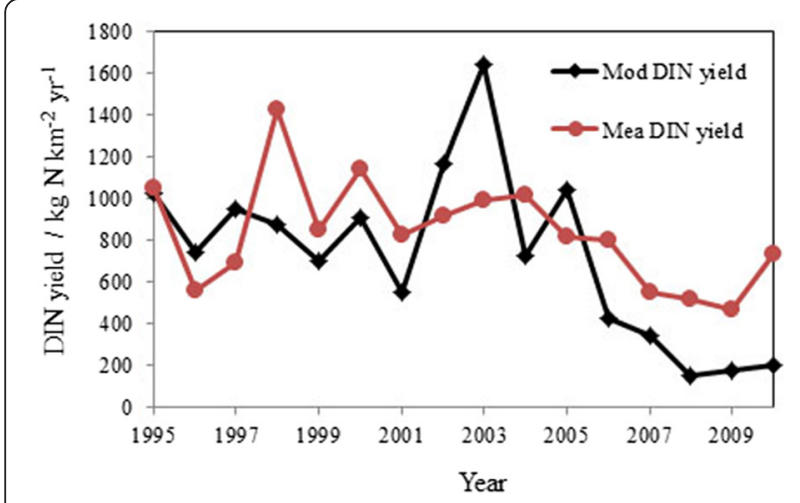

Fig. 7 Modeled and Measured DIN yield for Ganjiang River

with a $95 \%$ confidence interval over the period 1995-2010 $(\mathrm{n}=16, \mathrm{P}=0.234)$. Model errors vary from $-63.8 \% \sim 66.9$ $\%$ with the average value of $-10.8 \%$.

Modeled DIN yield from Ganjiang River varies from $151 \mathrm{~kg} \mathrm{~N} \mathrm{~km}^{-2} \mathrm{yr}^{-1}$ to $1645 \mathrm{~kg} \mathrm{~N} \mathrm{~km}^{-2} \mathrm{yr}^{-1}$ in 19952005, not showing remarkable changing trend (Fig. 7). However, it decreases significantly after 2005 and shows the same changing trend with measured values. In this case, modeled values are evidently lower than measured ones, which indicates that the model underestimates the DIN export for the Ganjiang River in the period 20052010. Moreover, the model does not catch the peak value of river DIN yield in the 1998 flood year.

From Fig. 7, we see that the modeled DIN yield is different from measured DIN yield in 2001-2004. That is because the TN exports, which accounts for about 46 $\%-62 \%$ of diffuse TN inputs, show abnormal variations in 2001-2004 (Fig. 3). In 2003, an extreme drought hit the whole Lake Poyang basin causing severe food reduction. In 2003, the rice yield in Jiangxi Province reached its lowest limit, which was $1.3 \times 10^{10} \mathrm{~kg}$. Simultaneously, the policy of returning farmland to forestland was carried out in whole province during 2001-2003 leading to the decrease of cultivated land area. Therefore, TN export by harvesting decreased significantly in these three years. The $\mathrm{FE}_{\mathrm{ws}-\text { fit }}$ plays a decisive role in the calculation of DIN yield for the Ganjiang River in the Global NEWS-DIN model. It is calculated based on the positive relationship with $\mathrm{RSD}(\mathrm{Eq}(16))$. According to Wang et al. 2014, the $R^{2}$ (determination coefficient) of the equation is 0.41 , which indicates that RSD can only explain $41 \%$ of the variation of $\mathrm{FE}_{\mathrm{WS} \text {-fit }}$. The model still needs adjustment considering other factors.

\section{Watershed $N$ retention}

In the Global NEWS-DIN model, $\mathrm{FE}_{\mathrm{WS}}$ is calculated as a simple function of runoff only, which does not exhibit long-term trends (Yan et al., 2010). In this article, we

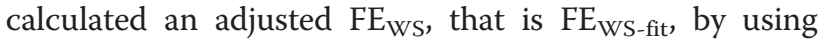

the watershed export coefficient model proposed by Wang et al. (2014) $(\mathrm{Eq}(6))$. The model is defined as

$$
F E_{W S-f i t}=2.75(R S D)-1.09
$$

Where, RSD represents the ratio of watershed $\mathrm{N}$ surplus against $\mathrm{N}$ input in the Ganjiang River watershed (Wang et al., 2014). It indicates that the lesser RSD is, the higher the capacity of watershed retention for nonpoint DIN inputs (1- FE $\mathrm{WS}_{\text {-fit }}$ ).

Comparison between $\mathrm{FE}_{\mathrm{WS}}$ and $\mathrm{FE}_{\mathrm{WS} \text {-fit }}$ (fitted or adjusted $\left.\mathrm{FE}_{\mathrm{WS}}\right)$ is shown in Fig. 8. It shows that, while $\mathrm{FE}_{\mathrm{WS} \text {-fit }}$ are substantially lower than $\mathrm{FE}_{\mathrm{WS}}$ in the period 1995-2010, they show the same decreasing trend, providing evidence for the recovering capacity of watersheds to retain $\mathrm{N}$ as nonpoint inputs decrease as a direct result of human activities. Variation of $\mathrm{FE}_{\mathrm{WS}}$ and $\mathrm{FE}_{\mathrm{WS} \text {-fit }}$ indicates that leaching and runoff from agricultural soils to surface water is not constant.

\section{Denitrification}

Denitrification is a critical process regulating the removal of bioavailable nitrogen $(\mathrm{N})$ from natural and human-altered systems (Seitzinger et al., 2006). In the Global NEWS-DIN model, DIN loss by denitrification during river transport is estimated as a simple function of drainage area, which does not exhibit long-term change trends (Dumont et al., 2005). However, the uncertainty lies in how the rates of denitrification will change as hydrology and geomorphology varythroughout the river network (Seitzinger et al., 2006). How rates of denitrification will respond to the varying loading of $\mathrm{N}$ in the watershed and how nutrient removal processes scale across the broad range of stream sizes that comprise river networks still remains uncertain (Fisher et al., 2004; Wollheim et al., 2006; Yan et al., 2012).

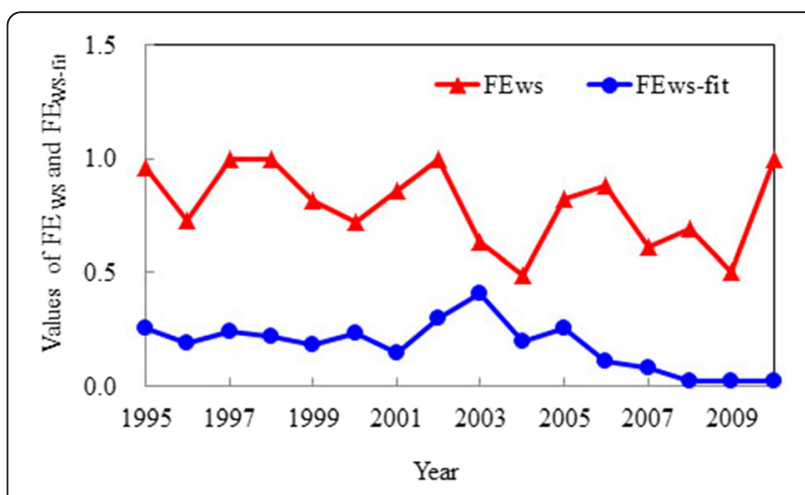

Fig. 8 Comparison between FE ws and FE $E_{W s-f i t}$ in the Ganjiang River watershed for the period 1995-2010 


\section{Conclusions}

Based on the quantitative analysis of nitrogen balance within the Gangjiang River watershed, the inputs of $\mathrm{N}$ and exports of DIN from Gangjiang River to Lake Poyang for the period 1995-2010 was estimated, by using the Global NEWS-DIN model. It shows that $\mathrm{N}$ inputs from nonpoint sources are approximately 10-54 times that from point sources. Almost all the diffuse DIN inputs were retained in the watershed before entering the lake Poyang. While about half of sewage $\mathrm{N}$ inputs were input to Lake Poyang as DIN from the Ganjiang River. Modeled DIN yield from Ganjiang River decreased after 2005 significantly, providing evidence for the recovering capacity of watersheds to retain DIN as inputs decrease as a direct result of human activities. The values of TSI (Trophic State Index) of Lake Poyang agree well with modeled DIN yields from the Ganjiang River. The study also demonstrates a varied contribution of different $\mathrm{N}$ inputs to river DIN yields during the study period. In the period 1995-2005, biological N fixation was the largest source of DIN yields, with a contribution ranging from $69.6 \%$ to $74.7 \%$. But after such interval, this contribution decreased significantly to $28.4 \%$ in 2010. Animal manure $\mathrm{N}$ inputs and atmospheric $\mathrm{N}$ inputs together accounted for about $10 \%$ of the total DIN yields in the period 1995-2005, showing a relatively stable trend. Sewage $\mathrm{N}$ inputs accounted for about $5.3 \%$ of DIN yields prior to 2005 , but this account increased significantly to $69.7 \%$ in 2010.The impact of climate change on the water environment of Lake Poyang was not clear due to lack of data on water quality in the basin. However, it plays a dominant role in changing basin hydrology and runoff in the Lake Poyang basin. More attention should be paid to reducing sewage $\mathrm{N}$ discharge to Lake Poyang in the background of global warming.

\section{Competing interests}

The authors declare that they have no competing interests.

\section{Authors' contributions}

$X L$ carried out the river DIN export study, participated in the sequence alignment and drafted the manuscript. $L Z$ provided some important data and methods guidance. GY and HL conceived of the study, and participated in its design and coordination. $\mathrm{BH}$ participated in the design of the study and the data processing. YC helped to draft the manuscript. XT performed the statistical analysis. All authors read and approved the final manuscript.

\section{Acknowledgment}

This work was funded by the Natural Science Foundation of China (41201496, 41271500), the Natural Science Foundation of Jiangsu Province (BK20141513), the Knowledge Innovation Program of the Chinese Academy of Sciences (KZZD-EW-10-04), Key "135" Project of Nanjing Institute of Geography and Limnology, Chinese Academy of Sciences (NIGLAS2012135005) and the Opening Fund of Key Laboratory of Poyang Lake Wetland and Watershed Research (Jiangxi Normal University), Ministry of Education (PK2014002). The authors greatly appreciate the time and effort given by anonymous reviewers and by the editors in evaluating our manuscript.
Received: 12 December 2014 Accepted: 4 August 2015

Published online: 27 August 2015

\section{References}

Barter M, Lei G, Cao L (2006) Waterbird survey of the middle and lower Yangtze River floodplain (February 2005). World Wildlife Fund-China and Chinese Forestry Publishing House, Beijing, China

Bouraoui F, Grizzetti B, Granlund K et al (2004) Impact of climate change on the water cycle and nutrient losses in a Finnish catchment. Climate Change 66:109-126

Catherine MO, Simone RA, Pierre DP, et al. (2003) Climate change decreases aquatic ecosystem productivity of Lake Tanganyika, Africa. Nature 242, 14 August.

Cui XH, Zhong Y, Chen JK (2000) Influence of a catastrophic flood on densities and biomasses of three plant species in Poyang Lake, China. Journal of Freshwater Ecology 15:537-541.

Duan SW, Zhang S, Huang HY, et al. (2000) Transport of dissolved inorganic nitrogen from the major rivers to estuaries in China. Nutrient Cycling in Agroecosystems 57:13-22.

Dumont E, Harrison JA, Kroeze C et al (2005) Global distribution and sources of dissolved inorganic nitrogen export to the coastal zone: Results from a spatially explicit, global model. Global Biogeochemical Cycles 19, GB4S02, doi:10.1029/2005GB002488.

Edwards DR, Daniel TC (1993) Effects of poultry litter application rate and rainfall intensity on quality of runoff from fescue frass plots. J Environ Qual 22:361-365

Fan JL, Hu ZY, Zhuang SY et al (2007) Observation of atmospheric nitrogen deposition into forestland. China Environmental Science 27(1):7-9 (in Chinese)

Fisher SG, Sponseller RA, Heffeman JB (2004) Horizons in stream biogeochemistry: Flowpaths to progress. Ecology 85:2369-2379

Guo H, Hu Q, Jiang T (2008) Annual and seasonal streamflow responses to climate and land-cover changes in the Poyang Lake basin, China. Journal of Hydrology 355:106-122

He B, Oki T, Kanae S, Mouri G, Kodama K, Komori D, Seto S (2009) Integrated biogeochemical modelling of nitrogen load from anthropogenic and natural sources in Japan. Ecological Modelling 220:2325-2334

He B, Kanae S, Oki T, Hirabayashi Y, Yamashiki Y, Takara K (2011) Assessment of global nitrogen pollution in rivers using an integrated biogeochemical modeling framework. Water Research 45(8):2573-2586. doi:10.1016/ j.watres.2011.02.011

Hydrology Bureau of Jiangxi Province. (1996-2012) Statistical yearbook of Jiangxi Province. Beijing: China Statistics Press

Hydrology Bureau of Jiangxi Province. (1999-2012) Jiangxi water resources bulletin. http://www.jxsl.gov.cn/slgb/szygb/index.html

Hydrology Bureau of Jiangxi Province. (1999-2012) Jiangxi Provincial Water Quality Bulletin. http://www.jxsl.gov.cn/list.jsp?classid=63

IPCC2014. State of the Climate (2014) http://www.jxsw.cn/Category_223/Index.aspx

Kistemann T, Claben T, Koch C et al (2002) Microbial load of drinking water reservoir tributaries during extreme rainfall and runoff. Applied and Environmental Microbiology, doi:10.1028/AEM.68.5.2188-2197

Kundzewicz ZW, Mata $\sqcup$, Arnell NW et al (2008) The implications of projected climate change for freshwater resources and their management. Hydrological Sciences-Journal-des Sceneces Hydrologiques 53(1)

Jia YF, Jiao SW, Zhang YM et al (2013) Diet shift and its impact on foraging behavior of Siberian Crane (Grus Leucogeranus) in Poyang Lake. PLOS ONE 8(6):1-9. doi:10.1371/journal.pone.0065843

Li XY, Li HP (2011) Temporal and spatial changes of nitrogen mass balance in a terrestrial ecosystem of Jiangxi Province, China. Acta Scientiae Circumstantiae 31(6):1320-1330.

Liu YB, Zhao XS, Wu GP (2014) A primary investigation on the formation of frequent droughts in the Poyang Lake basin in recent decade. Resources and Environment in the Yangtze Basin 23(1):131-138.

Liu, X.F. Transactions of Oceanology and Limnology. 1987, 1: 22-33.

Liu XJ, Zhang Y, Han WX et al (2013) Enhanced nitrogen deposition over China. Nature 494:459-462

Lv C Q and Tian H Q. (2007) Spatial and temporal patterns of nitrogen deposition in China: Synthesis of observational data. Journal of Geophysical Research 112, D22S05, doi:10.1029/2006JD007990

Mayorga E, Seitzinger SP, Harrison JA, et al. (2010) Global Nutrient Export from WaterSheds 2 (NEWS 2): Model development and implementation, Environ. Model. Softw., doi:10.1016/j.envsoft. 2010.01.007 
Min Q, Zhan LS (2012) Characteristics of low-water level changes in Lake Poyang during 1952-2011. Journal of Lake Sciences 24(5):675-578

OECD (2001) OECD national soil surface nitrogen balances: Explanatory notes [R]. Organization for Economic Cooperation and Development, Paris

Schneider P and Hook SJ (2010) Space observations of inland water bodies show rapid surface warming since 1985. Geophysical Research Letters 37, L22405. doi:10.1029/2010GL045059.

Tian HZ, Hao JM, Lu YQ, Zhu TL (2001) Inventories and distribution characteristics of NOx emissions in China. Environ Sci 21(6):493-497 (In Chinese)

Tian HZ, Hao JM (2003) Current status and future trend of nitrogen oxides emissions in China. Am. Chem. Soc., Div. Fuel Chem 48(2):764-765

Van Drecht G, Bouwman AF, Knoop JM, et al (2003) Global modeling of the fate of nitrogen from point and nompoint sources in soils, groundwater, and surface water. Global Biogeochemical Cycles 17(4). doi:10.1029/ 2003GB002060.

Van Drecht G, Bouwman AF, Harison J, et al (2009) Global nitrogen and phosphate in urban waste water for the period 1970-2050. Global Biogeochemical Cycles 23, GBOA03, doi:10.1029/2009GB003458.

Wan JB, Jiang ST (2005) Analysis and protecting countermeasures to water quality about Poyang Lake. Journal of Jiangxi Normal University (Natural Science) 29(3):260-263

Wang JN, Li XY, Yan WJ et al (2014) Watershed nitrogen export model related to changing nitrogen balance and hydrology in the Changjiang River basin. Nutr Cycl Agroecosyst 98:87-95

Wang SW, Zhang Q, Streets DG et al (2012) Growth in NOx emissions from power plants in China: bottom-up estimates and satellite observations. Atmos Chem Phys 12:4429-4447

Wang TJ, Liu Q, Zhao H et al (2008) Atmospheric nitrogen deposition in agr-ecosystem in red soil of Jiangxi Province. Acta Pedologica Sinica 45(2):280-287 (in Chinese)

Wang YY, Jia YF, Lei G et al (2013) Optimising hydrological conditions to sustain wintering waterbird populations in Poyang Lake National Natural Reserve: implications for dam operations. Freshwater Biology 58(11):2366-2379

Weyhenmeyer GA, Blenckner T, Pettersson K (1999) Changes in the plankton spring outburst related to the North Atlantic Oscillation. Limnology and Oceanography 44:1788-1792

Wiedner C, Rücker J, Brüggemann R, Nixdorf B (2007) Climate change affects timing and size of populations of an invasive cyanobacterium in temperate regions. Oecologia 152:473-484

Wollheim WM, Vorosmarty CJ, Peterson BJ, Seitzinger SP, and Hopkinson C.S. (2006) Relationship between river size and nutrient removal. Geophysical Research Letters, 33, doi:10.1029/2006GL025845.

World Bank (2001) The 2000 World Bank development idicators, data on CD-Rom, World Bank, 12 pp.

Wu LH, Li M, Guo YY, Yang XL (2011) Influence of three gorges project on water quality of Poyang Lake. Procedia Environmental Sciences 10:1496-1501

Yan WJ, Mayorga E, Li, XY, et al (2010). Increasing anthropogenic nitrogen inputs and riverine DIN exports from the Changjiang River basin under changing human pressures. Global Biogeochemical Cycles. 24,GBOA06, doi:10.1029/ 2009GB003575.

Yan WJ, Yang LB, Wang F et al. (2012) Riverine N2O concentrations, exports to estuary and emissions to atmosphere from the Changjiang River in response to increasing nitrogen loads. Global Biogeochemical Cycles 26, GB4006, doi:10.1029/2010GB003984.

Yan WJ, Zhang S, Sun P et al. (2003) How do nitrogen inputs to the Changjiang basin impact the Changjiang River nitrate: A temporal analysis for 1968-1997. Global Biogeochemical Cycles 17, doi:10.1029/2002GB002029.

Yang LZ, Sun B, Fan XH et al (2009) Nutrient cycles, balance, and management in agricultural ecosystems of China. Science Press, Beijing, pp 86-199 (in Chinese)

Ye XC, Zhang Q, Liu J et al (2013) Distinguishing the relative impacts of climate change and human activities on variation of streamflow in the Poyang Lake Catchment, China. Journal of Hydrology 494:83-95

\section{Submit your manuscript to a SpringerOpen ${ }^{\odot}$ journal and benefit from:}

- Convenient online submission

- Rigorous peer review

- Immediate publication on acceptance

- Open access: articles freely available online

- High visibility within the field

- Retaining the copyright to your article

Submit your next manuscript at $\gg$ springeropen.com 